\title{
Understanding Sclerotinia Risks Associated with Growing Peanuts in the South Burnett Area ${ }^{+}$
}

\author{
Claire-Marie Pepper 1,2 \\ 1 School of Health, Medical and Social Sciences, Central Queensland University, Bundaberg, QLD 4670, \\ Australia; c.pepper@cqumail.com \\ 2 Northern Agriservices, Kingaroy, QLD 4610, Australia \\ + Presented at the third International Tropical Agriculture Conference (TROPAG 2019), Brisbane, Australia, \\ 11-13 November 2019.
}

Published: 6 April 2020

\begin{abstract}
Sclerotinia Blight, caused by ascomycete fungal pathogen S. minor (Jagger), is a serious soil-borne disease of peanut crops within the South Burnett area in Queensland, Australia. The pathogen can infect root, stem and foliage tissues, forming characteristic fluffy white mycelial growth on stems leading to tissue wilting and necrosis. The disease can cause significant yield reductions and, in some cases, complete crop losses in peanut production. Outbreaks occur in cooler weather (under $18^{\circ} \mathrm{C}$ ) with high humidity levels (above 95\%) as the higher humidity levels promote germination of sclerotia (Smith 2003, Maas, Dashiell et al. 2006). Therefore, knowledge of inoculum levels prior to sowing could enhance cropping systems through enhanced capacity to predict outbreaks. The South Australia Research and Development Institute (SARDI) offers a new soil test for Sclerotinia sp., called PreDictaB, available for farmers to asses inoculum levels pre-planting as a crop risk assessment tool. This project validated the accuracy of the PreDictaB test for Sclerotinia inoculum levels in the South Burnett soils, while gathering paddock and weather data to identify key characteristics linked to high risk of Sclerotinia Blight incidence to be transposed in a pre-season risk matrix model. Results demonstrated a close positive relationship between the level of Sclerotinia in the soil pre-planting and the paddock disease severity observed at harvest. The significance of the results for future research into potential management strategies is discussed. This new test has the potential to reduce the impact and presence of Sclerotinia in the field within the South Burnett region.
\end{abstract}

Keywords: fungal disease; Sclerotinia; peanuts; South Burnett; honours project; PreDictaB; Queensland; broadacre research; disease in peanuts; risk assessment

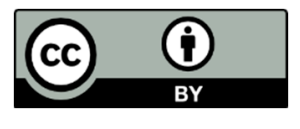

(C) 2020 by the authors. Licensee MDPI, Basel, Switzerland. This article is an open access article distributed under the terms and conditions of the Creative Commons Attribution (CC BY) license (http://creativecommons.org/licenses/by/4.0/). 